application of Kirchhoff's law sometimes leads students to imagine that the two quantities are identical, but Kirchhoff's law applies only to purely thermal radiation ( $c f$. Wood's "Physical Optics," chapter xix.). A gas, such as hydrogen, in its non-luminous condition does not absorb selectively the light emitted by luminous hydrogen. I do not think that any absorption bands in non-luminous hydrogen have been detected; they are probably far in the ultra-violet, and there is no reason for supposing that their wave-lengths will be connected by any formula similar to that of Balmer.

The reason for the difference in the frequencies of the absorption bands and the lines in the emission spectrum is sufficiently obvious. The emission of light by a gas is doubtless connected with the ionisation of its atoms. But, when an atom is ionised, the electrons in or surrounding that atom are subject to forces entirely different from those which act upon them when the atom is ionised; there must be a corresponding difference in the periods of free vibration. The absorption bands probably represent the vibrations of the electrons in the neutral atom, the emission spectrum those of the electrons in or around the ionised atom.

Nor is there any reason why the refractive index of a luminous gas should differ greatly from that of a nonluminous gas, except in the immediate neighbourhood of a line in the emission spectrum. (It is relevant to note that Drude's formula cannot be applied to such regions.) Only a very small proportion of the total number of atoms present is ionised even under the most favourable experimental conditions; most of the atoms are not ionised, and affect the light in the same way as those of a non-luminous gas. Of course, if the refractive index due to the luminous atoms were really infinite, the refractive index of the luminous gas would be infinite, however small the proportion of luminous atoms. But it is impossible that it should be infinite; if Balmer's formula were accurately true for all values of $m$, there would be an infinite number of lines in the emission spectrum, implying an infinite number of degrees of freedom in the vibrating system. According to the modern view, which seems to be accepted by Prof. Schott, this system is composed of discrete charged particles possessing a finite mass; the number of such particles must be finite, and they can only have a finite number of degrees of freedom. Experiment can never demand an infinite number of lines, for, if $m$ is very great, the lines are so close as to be beyond the range of resolution.

Trinity College, Cambridge.

\section{The Oligochætous Fauna of Lake Birket el Qurun and Lake Nyassa.}

IN Nature of August I, I907 (vol. Ixxvi., p. $3^{16}$ ), Messrs. Cunnington and C. L. Boulenger wrote a preliminary account of the fauna of Lake Birket el Qurun. I am indebted to these gentlemen for the opportunity of supplementing their account by a note upon the Oligochæta of that lake. They were so good as to send to me two tubes with a large number of specimens of a small oligochætous worm collected in the lake. These specimens were found to belong, without exception, to the species Paranais littoralis. The occurrence of this Naid in northern Africa is a new fact in its distribution. It has hitherto been met with in many parts of Europe, both in fresh water and in brackish, even salt, water. As to its marine habitat, it has been collected on the shores of Denmark and near Odessa.

It is clear from the fact that this was the only aquatic Oligochæte met with by Messrs. Cunnington and Boulenger that it must at least be a prevalent form in the lake.

Mr. Cunnington has also kindly placed in my hands some examples of aquatic Oligochæta from Lake Nyassa. These belong to three species, and the contrast with the oligochætous fauna of the North African lake is very marked. The genera represented in Nyassa are Dero, Nais, and Pristina. Unfortunately, none of the examples No. 2009, VOL. 77] submitted to me are sexually mature. The Pristina I identify with Pristina longiseta, a widely spread form The genera Nais and Dero are also found in many parts of the world, and as all three genera have already been recorded from tropical East Africa (Michaelsen in Zeitschr. f. wiss. Zool., Bd. Ixxxii., I905, p. 289), there is no cause for surprise at their occurrence in Nyassa. Still, the fact seemed to me to be worth putting on record.

Zoological Society's Gardens.

Frank E. BEDdard.

\section{THE FORTHCOMING DUBLIN MEETING OF THE BRITISH ASSOCIATION.}

THE British Association will hold its fourth meeting in Dublin on September $2-8$ of this year. The three previous meetings took place in 1835 , in 1857 , and in 1878 . The 1878 meeting drew an attendance of 2578 , which was well above the average, and it was marked by the presence of an unusually large number of men distinguished in scientific or other work at the time and since. In his presidential address before the Anthropology Section, Prof. Huxley spoke prophetically about those " who may be here thirty years hence-I certainly shall not be," little realising how both his prophecies were destined to come true.

Appropriately enough (though, I believe, not consciously in connection with Huxley's forecast), the invitation for 1908 originated with Prof. W. $H$. Thompson, of the physiological laboratory of Dublin University. It was originally intended for 1907 , but I908 was found to be more suitable, and the invitation was formally accepted at York in 1906, where a deputation attended consisting of the Provost of Trinity College, Prof. Thompson, Dr. Tarleton, Monsignor Molloy, Rev. Dr. Delaney, and the Lord Mayor of Dublin. The invitation was formally renewed at Leicester by Prof. Thompson, Rev. Dr. Delaney, and Sir Howard Grubb. At a first meeting at the Dublin Mansion House, general and executive committees were appointed, and these have been at work ever since, with the result that the arrangements are in an advanced state of preparation. Subcommittees were appointed to deal with finance, entertainments, hospitality, and the handbook respectively. The four local secretaries are Dr. Joseph McGrath, secretary of the Royal University, Prof. W. E. Thrift, Prof. W. H. Thompson, and Mr. John Mulligan, of the Hibernian Bank. About $3000 l$. has already been subscribed towards the expenses of the meeting. The reduced fare tickets will be available for a month, so as to include the excursions subsequent to the official meeting. Day excursions will be arranged during the week of the meeting to the Devil's Glen and Glendalough in county Wicklow, to Powerscourt Waterfall and the Dargle near Bray, to the Boyne Valley, and to the Shannon Lakes.

The presidential address will be delivered by $\mathrm{Mr}$. Francis Darwin, F.R.S., on the evening of Wednesday, September 2, in the large hall of the Royal University. Here also will be delivered two of the evening discourses, one on "Halley's Comet," by Prof. H. H. Turner, F.R.S. (Friday, September 4), the other on "The Lessons of the Colorado Cañon," by Prof. W. M. Davis, of Harvard University (Monday, September 7). The third evening discourse will be delivered to operatives on Saturday, September 5 . To this discourse ordinary members will not be admitted. The lecture hall has not yet been decided upon.

The serious work of the sections will, for the most part, be over each day by two o'clock, leaving the 
afternoon, and those evenings on which discourses are not held, free for entertainments of a social kind. Of the latter, not a few are already promised, including garden-parties by their Excellencies the Lord Lieutenant and the Countess of Aberdeen, by Lord and Lady Ardilaun, and by the provost and senior fellows of Trinity College; evening receptions are also to be held by the Viscount and Viscountess Iveagh, by the Royal Dublin Society, and by the Royal Irish Academy. The Lord Mayor and Lady Mayoress will be "At Home" at the Mansion House, to members of the association, on the afternoon of the opening day of the meeting.

The work of the Dublin meeting will be transacted in twelve sections, which, with their respective presidents, are as follows :- Mathematical and Physical Science (Dr. W. N. Shaw, F.R.S.); Chemistry (Prof. F. S. Kipping, F.R.S.); Geology (Prof. J. Joly, F.R.S.); Zoology (Dr. S. F. Harmer, F.R.S.); Geography (Major E. H. Hills, R.E.); Economic Science and Statistics (Mr. W. M. Acworih); Subsection Agriculture (Sir Horace Plunkett, K.C.V.O., F.R.S.); Engineering (Mr. Dugald Clerk, F.R.S.); Anthropology (Prof. W. Ridgeway); Physiology (Dr. J. S. Haldane, F.R.S.; Botany (Dr. F. F. Blackman, F.R.S.); Educational Science (Prof. L. C. Miall, F.R.S.). To increase the general interest in the doings of the association, these sections have been distributed over various institutions in the city, the governing bodies of which have kindly undertaken to provide suitable accommodation. Thus, Trinity College, the Royal University, the Royal College of Science, University College, the Royal Colleges of Physicians and Surgeons, the Royal Irish Academy, and the Royal Dublin Society all vie with each other in this respect.

The reception room and administrative offices during the meeting will be located in Trinity College. Until then, offices for the local reception committee have been kindly provided at the Royal University by permission of the Senate.

The official handbook is being prepared by $\mathrm{Mr}$. R. Lloyd Praeger (author of "Irish Topographical Botany") and Prof. Grenville A. J. Cole, under the auspices of the Handbook Committee. It will comprise sections on local geology, botany, zoology, history and archæology, commerce and industries, and the usual official information. Among the articles will be one on glacial phenomena, by $\mathrm{Mr}$. J. R. Kilroe, and another on mineralogy, by Mr. H. J. Seymour, both of the Geological Survey. Mr. Nathaniel Colgan, author of "Flora of Co. Dublin", and one of the editors of "Cybele Hibernica," will deal with botanical subjects. The zoology section will be prepared by Prof. G. H. Carpenter, and will comprise an essay on Irish mammals, by Dr. Scharff; birds, by Mr. R. M. Barrington (author of "Migration of Birds"); and numerous other special articles.

The history and archæology of the district round Dublin will be in charge of Mr. C. Litton Falkiner, secretary to the council of the Royal Irish Academy, and Mr. Elrington Ball (author of "History of the "Flora of Co. Dublin" and one of the editors of Murray's "Guide to Ireland") will deal with the prehistoric and other antiquities of the Boyne Valley, including the famous tumuli of Knowth, Dowth, and Newgrange, and with Dublin churches. There will also be articles by $\mathrm{Mr}$. J. Westropo on the mediæval and ecclesiastical antiquities of Dublin and Wicklow; by Count Plunkett, the new director of the Dublin Museum, on old Dublin houses; and by Dr. Cosgrave, on old views of Dublin.

Dublin possesses attractions which very few capital cities can rival. Situated in the centre of Dublin Bay, its beautiful and prosperous suburbs extend northwards on to the promontory of Howth and south. wards to Kingstown, Dalkey, and the far-famed Bay of Killiney, which, closed in by the Wicklow Mountains, presents an aspect of unsurpassed beauty.

A somewhat unusual element of local colour.will be given to this year's Dublin meeting by the large number of bilingual street name-plates and signposts (an outcome of the Gaelic revival), on which the historic names are given in both Irish and English character and spelling. The well-known cordiality and hospitality of the Irish people may be trusted to render this year's visit of the devotees of science one of particularly agreeable memories.

E. E. F.

\section{THE SCIENCE COURT OF THE FRANCO. BRITISH EXHIBITION.}

THE fact that pure science will take a recognised part in the scheme of the forthcoming FrancoBritish Exhibition, and that it is being assigned a court specially for this subject, has already been re. corded in these columns. It is believed that this is the first large exhibition at which such distinct recognition of the claims of pure science has been made, and it may be welcomed as being an example which should be followed at all future exhibitions.

The scheme of the court has been arranged so as to show apparatus and processes of historical value in the various sciences, and also, so far as possible, to illustrate various researches in science, both in the laboratory and in the factory, which have beeil and are being carried on. The exhibits will be arranged under the head of each of the great sciences, with subdivisions where necessary. Arrangements have also been made to illustrate the nature of the scientific work which is being carried on under the head of the exploration of the heavens, the air, the sea, and the land, which come naturally under the sciences of astronomy, meteorology, oceanography, geography, and geology. In this way it is hoped that a fairly complete review of all the important sciences will be obtained.

In the previous article in NaTure, the constitution and names of the full committee and of the various subcommittees were given. The preliminary arrangements and discussion of the principles to be followed, and the nature of exhibits to be asked for, occupied the committee several months, but the work of actually collecting the exhibits in each science which are to be shown was handed over by the committee to the various subcommittees and their respective Conveners, as they are the best and most appropriato judges of what exhibits are available. These sub. committees and their Conveners have really had a hard and difficult task in making representative and interesting collections, but they have, on the whole, been most successful.

The usual difficulties in securing historically valuable apparatus have been experienced, and mani individuals and institutions have not found themselves able to allow such apparatus to pass out of their own custody. Further difficulties have also arisen, as is usual in such cases, in the matter of space and funds, for both have had to be provided by the exhibition itself, as no public funds have been forthcoming. The executive committee has generously given a court, comprising the space of about 14,000 square feet, free of cost, for the science exhibits, and has placed at the disposal of the science committee 